\title{
Sertoli cells as paracrine modulators of DNA synthesis in rat peritubular myoid cells in culture
}

\author{
S. S. Raychoudhury ${ }^{1 *}$, E. W. Thompson ${ }^{2}$, A. W. Blackshaw ${ }^{3}$ and \\ M. G. Irving ${ }^{4}$ \\ ${ }^{1}$ Division of Science and Technology, Griffith University, Brisbane, Queensland 4111, Australia; \\ ${ }^{2}$ Vincent Lombardi Cancer Research Center, and Department of Anatomy and Cell Biology, \\ Georgetown University Medical Center, Washington DC 20007, USA; ${ }^{3}$ Department of Physiology \\ and Pharmacology, University of Queensland, St Lucia, Queensland 4072, Australia and \\ ${ }^{4}$ Gold Coast University College of Griffith University, Queensland, Australia
}

\begin{abstract}
To determine whether Sertoli cells influence DNA synthesis by rat peritubular myoid cells in vitro, the effects of Sertoli cells on $\left[{ }^{3} \mathrm{H}\right]$ thymidine incorporation by peritubular myoid cells in a coculture situation were examined. Incubation of testicular peritubular myoid cells with Sertoli cells in coculture induced a significant increase in $\left[{ }^{3} \mathrm{H}\right]$ thymidine incorporation by peritubular myoid cells. This indicates a cell-cell cooperation between Sertoli and peritubular myoid cells in the testis in terms of DNA synthesis. Secreted factors from Sertoli cells, as tested in a parabiotic culture situation, also increased $\left[{ }^{3} \mathrm{H}\right]$ thymidine incorporation by peritubular myoid cells. Moreover, in terms of total cellular protein, cocultures of Sertoli cells and peritubular myoid cells resulted in a significant increase when compared with the monocultures, and this coculture effect substituted for the stimulatory response of serum on peritubular myoid cell monoculture. This study investigated the cooperative role of Sertoli cells and peritubular myoid cells in paracrine regulation of testicular functions.
\end{abstract}

\section{Introduction}

In the intact testis, Sertoli cells and peritubular myoid cells are adjacent to each other in the boundary tissue of the seminiferous tubule, separated by a basal lamina. Peritubular myoid cells surround the tubule adjacent to the basal surface of the Sertoli cells. Interactions between these two cell types are important in the regulation of the functions of the seminiferous tubules, including maintenance of the chemical milieu required for spermatogenesis. Metabolic cooperation between Sertoli cells and peritubular myoid cells has been reported (Hutson, 1983), and the ability of peritubular myoid cells to modulate Sertoli cell function in coculture has been established (Tung and Fritz, 1980; Hutson and Stocco, 1981; Skinner and Fritz, 1985; Janecki and Steinberger, 1987).

Sertoli cells secrete various proteins and, thereby, regulate the environment in the seminiferous tubule. Some of the effects of Sertoli cells on peritubular myoid cells are thought to be mediated by components secreted by Sertoli cells or by cell-cell contact through the extracellular matrix. Proteins secreted by Sertoli cells stimulate DNA synthesis and proliferation of DDT 1 MF-2 smooth muscle cells, A431 and Swiss 3 T3 cell lines (see review, Bellvé and Zheng, 1989) and stimulate rat Leydig cell DNA synthesis (Ojeifo et al., 1990). These reports raise the possibility that Sertoli cell association may act as a paracrine

*Present address: University of South Carolina School of Medicine, Department of Cell Biology and Neurosciences, Columbia, SC 29208, USA.

Received 31 December 1992 regulator of peritubular myoid cell DNA synthesis and, consequently, proliferation. To test this hypothesis, we examined the effects of Sertoli cells isolated from three-week-old rats on $\left[{ }^{3} \mathrm{H}\right]$ thymidine incorporation by peritubular myoid cells in culture to determine whether Sertoli cells influence DNA synthesis by peritubular myoid cells. This study emphasizes that the paracrine regulation of testicular function is dependent on cooperation between Sertoli cells and peritubular myoid cells.

\section{Materials and Methods}

\section{Animals}

Testes from 20-22-day-old white Wistar rats were used for cell culture. Rats were obtained from the breeding colony of the University of Queensland and housed in two groups of ten in each cage. Animals were given rat chow and water ad libitum.

\section{Chemicals}

Type II collagenase, hyaluronidase Type I-S, trypsin inhibitor Type I-S, hyaluronic acid Grade-IIIS and BSA Fraction V were purchased from Sigma Chemical Company (St Louis, MO). Trypsin, heparin, Eagle's minimum essential medium with Earle's salts (MEM) and Hank's balanced salt solution (HBSS) were obtained from Commonwealth Serum Laboratory (Melbourne). $\mathrm{Ca}^{2+}$ - and $\mathrm{Mg}^{2+}$-free HBSS and fetal calf serum (FCS) were supplied by Gibco Laboratories (Grand Island, NY). 
DNAase Type I was obtained from Calbiochem (La Jolla, CA). Tissue culture plates and flasks were from Nunc (Roskilde). Methyl $\left[{ }^{3} \mathrm{H}\right]$ thymidine $\left(2 \mu \mathrm{Ci}\right.$ per dish, $\left.5.0 \mathrm{Ci} \mathrm{mmol}^{-1}\right)$ and scintillant was purchased from Amersham International (Amersham).

\section{Preparation and culture of enriched populations of Sertoli cells and peritubular myoid cells}

Twenty rats were killed by decapitation for each cell preparation and culture procedure. Enriched populations of Sertoli cells were prepared by a modification of the procedures of Dorrington et al. (1975), as described by Tung and Fritz (1977) and Tung et al. (1984). Briefly, testes were aseptically removed, decapsulated and minced into $0.5 \mathrm{~mm}$ segments. The chopped tubules were suspended in $50 \mathrm{ml}$ of $\mathrm{Ca}^{2+}$. and $\mathrm{Mg}^{2+}$-free HBSS and incubated at $37^{\circ} \mathrm{C}$ in a shaker water bath with $0.25 \%$ trypsin (to remove interstitial cells) and $700 \mu \mathrm{l}$ of DNAase $\left(1 \mathrm{mg} \mathrm{ml}^{-1}\right)$ for $30 \mathrm{~min}$, followed by a washing through a sterilized stainless steel grid $\left(0.6 \mathrm{~mm}^{2}\right)$ with $10 \mathrm{ml}$ HBSS plus trypsin inhibitor $\left(2 \mathrm{mg} \mathrm{ml}^{-1}\right)$. The tubules were further digested in $20 \mathrm{ml}$ HBSS containing collagenase ( $1 \mathrm{mg} \mathrm{ml}^{-1}$ ), hyaluronidase $\left(1 \mathrm{mg} \mathrm{m}^{-1}\right.$ ) and $100 \mu \mathrm{l}$ of DNAase ( $1 \mathrm{mg} \mathrm{m}^{-1}$ ) for $30 \mathrm{~min}$. After a brief low speed centrifugation ( $2 \mathrm{~min}$ at $30 \mathrm{~g}$ ), the pellet was further digested with hyaluronidase ( $1 \mathrm{mg} \mathrm{ml} \mathrm{ml}^{-1}$ ) and $100 \mu \mathrm{l}$ of DNAase $\left(1 \mathrm{mg} \mathrm{ml} \mathrm{m}^{-1}\right)$ in $20 \mathrm{ml}$ of HBSS for another $30 \mathrm{~min}$ and the supernatant was saved for isolation of peritubular myoid cells. The resultant cell aggregates were washed with $1 \%$ BSA in HBSS and plated on $35 \mathrm{~mm}$ Petri dishes in serum-free MEM. Cell viability was routinely determined by Trypan blue exclusion. More than $95 \%$ of the cultured cells were viable. Most of the dead cells appeared to be spermatocytes and these cells were removed after five changes of medium during the culture period.

Representative cell cultures were examined by phase-contrast microscopy and the morphological features of Sertoli cells and peritubular myoid cells were occasionally assessed by transmission electron microscopy. In this study, Sertoli cell monolayers were more than $95 \%$ free of peritubular myoid cell contamination. Most of the ultrastructural features including prominent nuclei were observed in Sertoli cell preparations. The cytoplasm contained large numbers of mitochondria with transversely oriented folinate cristae and dark matrix. Lipid droplets were often present. An abundance of agranular endoplasmic reticulum was also observed. The cells were in tight apposition to one another, forming a characteristic cell border. These structural components are not present in any other cells in the testicular cultures, and are morphological features of Sertoli cells in vivo (Fawcett, 1975; Gilula et al., 1976). Peritubular myoid cells had abundant granular endoplasmic reticulum with dilated cisternae and cytoplasmic filaments in the cytoplasm. Under the influence of serum, these cells appeared large, flat-shaped and occasionally binucleate. In these cultures, we did not observe any cells having the ultrastructural characteristics of Leydig cells or endothelial cells from blood vessels.

Peritubular myoid cells were isolated from the collagenasehyaluronidase supernatant according to procedures described by Tung et al. (1984); Skinner and Fritz (1985). These cells were cultured in MEM containing 10\% FCS and grown to confluence, subcultured on day 4 , and replated in serum-free MEM at a cell density of approximately $2 \times 10^{5}$ in $35 \mathrm{~mm}$ plastic culture dishes either alone or in coculture with Sertoli cells previously cultured for 4 days in serum-free medium. Subcultured peritubular myoid cells were also replated in MEM containing 10\% FCS and they were confluent after 3-4 days of culture. Sertoli cell-enriched primary cultures were maintained in serum-free MEM that contained $1 \times 10^{\circ}$ cells per $35 \mathrm{~mm}$ plastic culture dish. Both cell types were also maintained in parabiotic culture dishes prepared by embedding a strip of non-wettable plastic across the middle of a $35 \mathrm{~mm}$ Petri dish with silicone grease (Dow Corning D1400). Parabiotic cultures had Sertoli cells on one side and peritubular myoid cells on the other side of the partition. Cells on each side of the partition were allowed to attach in individual chambers. Twenty-four hours later, the partition was submerged with $4 \mathrm{ml}$ MEM in the absence of serum, allowing humoral contact between each chamber of the dish. Preliminary studies included varying incubation times and concentrations of radioactive $\left[^{3} \mathrm{H}\right]$ thymidine. After determination of the optimum conditions, all cultures were incubated with $\left[{ }^{3} \mathrm{H}\right]$ thymidine $\left(2 \mu \mathrm{Ci}\right.$ per dish) for $96 \mathrm{~h}$ at $37^{\circ} \mathrm{C}$ in a humidified $5 \% \mathrm{CO}_{2}$ incubator. At $37^{\circ} \mathrm{C}$, most of the contaminating germ cells were dead and removed by day $\mathrm{I}$ of culture with little or no impairment of Sertoli cell functions (Hall et al., 1985; Raychoudhury et al, 1993a).

In addition to the morphological criteria described above, a histochemical assay of Sertoli cells and peritubular myoid cells was also conducted to check culture purity. The procedure of Chapin et al. (1987) was used for histochemical demonstration of alkaline phosphatase activity on cover-slip cultures. More than $85 \%$ of cells from the peritubular myoid cell preparations stained blue (alkaline phosphatase-positive), whereas less than $1 \%$ of cells from the Sertoli cell preparations exhibited alkaline phosphatase activity. In Sertoli cell preparations, more than $95 \%$ of cells stained for neutral lipid as observed with Oil Red O staining (Raychoudhury et al., 1993a). To check for possible Leydig cell contamination in the Sertoli and peritubular myoid cell preparations, cultures were stained histochemically for $3 \beta$-hydroxysteroid dehydrogenase $(3 \beta$-HSD) (Welsh and Wiebe, 1975). In the serum-free Sertoli cell-enriched preparations and in the peritubular myoid cell preparations, there were virtually no $3 \beta$-HSD-positive cells. Moreover, when desmin histochemistry was performed on these culture preparations (Raychoudhury et al., 1993b), approximately $80 \%$ of the cells from peritubular myoid cell preparation were stained desmin-positive but fewer than $1 \%$ of the cells from the Sertoli cell preparations were stained for this protein. The remaining unstained cells in the peritubular myoid cell preparation, showing no or very little staining for either alkaline phosphatase or desmin, could be undifferentiated peritubular myoid cells. Both morphological and histochemical identification of cells provided evidence of cell purity for the Sertoli and peritubular myoid cell cultures.

\section{$[3]$ thymidine incorporation assay}

Measurement of radioactivity. On day 8 of culture (after $96 \mathrm{~h}$ of labelling), the cells were solubilized with $20 \mathrm{mmol}$ ammonium hydroxide $1^{-1}$. The plates were washed twice with phosphate-buffered saline and combined with the sample. These cells were further solubilized with $1 \%$ SDS for $30 \mathrm{~min}$ at $22^{\circ} \mathrm{C}$ and 

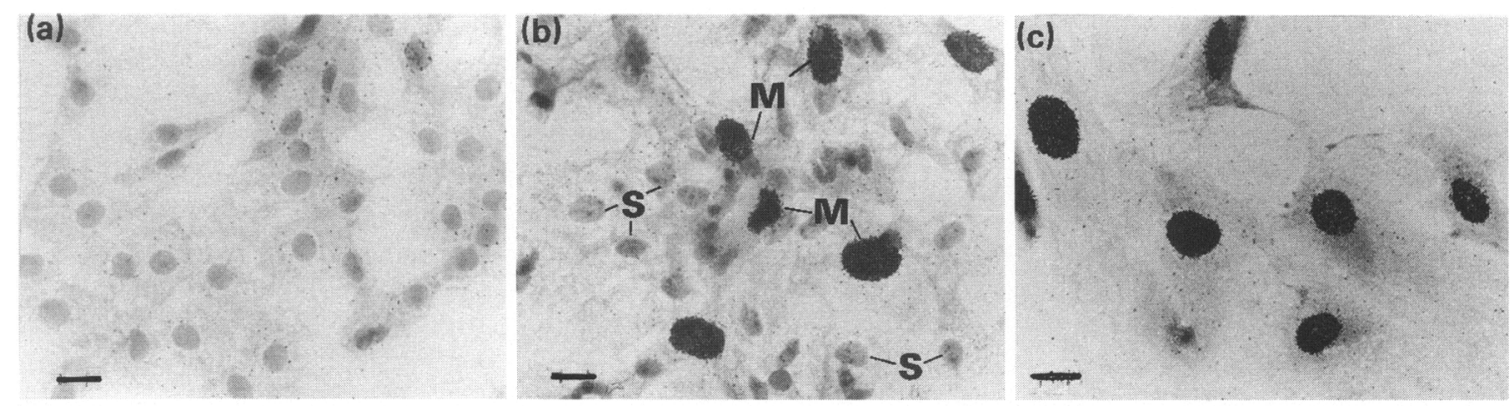

Fig. 1. Autoradiographs of Sertoli cells and peritubular myoid cells from rat testes in culture. (a) Sertoli cell-enriched primary cultures were maintained in serum-free minimum essential medium (MEM) and these cells in monoculture showed very few labelled nuclei. (b) Peritubular myoid cells were cultured in MEM containing 10\% fetal calf serum (FCS), subcultured on day 4 and plated in serum-free MEM in coculture with Sertoli cells previously cultured for 4 days in serum-free condition. In Sertolimyoid cell cocultures, most of the peritubular myoid cells $(\mathrm{M})$ appeared heavily labelled, whereas a very small proportion of Sertoli cells (S) showed some lightly labelled nuclei but were mostly unlabelled. (c) Subcultured peritubular myoid cells replated in MEM containing 10\% FCS showed a widespread distribution of labelled nuclei throughout the culture. All cultures were incubated with $\left[{ }^{3} \mathrm{H}\right]$ thymidine $(2 \mu \mathrm{Ci}$ per dish) for $96 \mathrm{~h}$. Stain: haematoxylin and eosin. Scale bar $=10 \mu \mathrm{m}$.

transferred to a tube containing $10 \mu \mathrm{g} \mathrm{BSA}$ as carrier protein at $4^{\circ} \mathrm{C}$. DNA was precipitated with $1 \mathrm{ml}$ of $20 \%$ trichloroacetic acid (TCA) for $30 \mathrm{~min}$ at $4^{\circ} \mathrm{C}$ and collected on a Millipore filter $(0.45 \mu \mathrm{m})$. This method was essentially based on the technique used by Mans and Novelli (1961). Filters were washed with 5\% TCA at $4^{\circ} \mathrm{C}$, dried and radioactivity determined in toluene-based scintillant on a Packard 2000 TRI-CARB liquid scintillation analyser. The background binding of the $\left[{ }^{3} \mathrm{H}\right]$ thymidine to the filter disc which ranged from 70 to 100 c.p.m. was subtracted in all cases before calculation of DNA synthesis data.

Autoradiography. In other experiments, autoradiography was used to identify cells that had incorporated $\left[{ }^{3} \mathrm{H}\right]$ thymidine into nuclei. On day 8 of culture (after $96 \mathrm{~h}$ of labelling), coverslips containing cultured preparations were washed twice in $0.9 \%$ sodium chloride and fixed in acidic ethanol ( $\mathrm{I}$ part acetic acid to 3 parts absolute ethanol, v:v) for $30 \mathrm{~min}$ at $22^{\circ} \mathrm{C}$. The fixed cells were washed with absolute ethanol and held in $70 \%$ ethanol until processed. Fixed cells on cover-slips were washed and mounted to microscope slides. Those slides were prepared for Ilford K-2 nuclear emulsion dipping using a slightly modified method of Marshall et al. (1980). The coated slides were stored at $4^{\circ} \mathrm{C}$ in light-tight slide boxes containing silica gel for the $24 \mathrm{~h}$ exposure time. The slides were developed in the darkroom using Kodak D-19 developer (5 min) and fixed in Ilfofix (10 min). After washing in running water, the slides were stained in haematoxylin $(1 \mathrm{~min})$ and eosin $(20 \mathrm{~s})$, dehydrated and cleared in xylene. The slides were then placed in acetone to dissolve the mounting medium. The cover-slip cultures were dehydrated and cleared once more and remounted onto fresh slides using Styrex $(250 \mathrm{~g}$ styron, $700 \mathrm{ml}$ xylol and $100 \mathrm{ml}$ dibutylphthalate). Cell counts were performed on autoradiograph slides and the percentage of labelled cells was obtained by counting $500-1000$ cells per slide in random fields at $\times 128$ magnification.

\section{Determination of cellular protein}

The protein content of cells was assayed by the method of Lowry et al. (1951) using BSA (1 $\left.\mathrm{mg} \mathrm{ml}^{-1}\right)$ as a standard.

\section{Determination of cellular DNA}

The DNA content of cells was determined fluorimetrically by the ethidium bromide method (Karsten and Wollenberger, 1977; Louis and Fritz, 1979).

\section{Statistical analysis}

Each experiment was repeated at least five times in duplicate samples to confirm reproducibility of the results. $\left[{ }^{3} \mathrm{H}\right]$ thymidine incorporation was measured by scintillation counting and standardizing c.p.m. data per $10^{6}$ cell number basis. The percentage of nuclei labelled was calculated from the number of labelled cell nuclei, divided by the total number of nuclei scored, multiplied by 100 . Percentage values were transformed to angles (arc sin $\sqrt{ } \%$ ) before analysis. Analysis of variance was conducted using SAS (1985) statistical package, and where significant, individual means were compared by least significant difference $(P<0.05)$.

\section{Results}

\section{$\left[^{3}\right.$ H]thymidine incorporation}

DNA synthesis in individual cell cultures was studied by autoradiography as an index of cell proliferation. Sertoli cell monocultures showed very few labelled nuclei (Fig. 1a). In Sertoli-myoid cell cocultures, most of the peritubular myoid cells appeared heavily labelled, whereas a very small proportion of Sertoli cells showed lightly labelled nuclei or were unlabelled (Fig. 1b). Peritubular myoid cells cultured in the presence of $10 \%$ FCS, showed a wide distribution of labelled nuclei throughout the culture (Fig. Ic). Under serum-free conditions, peritubular myoid cells in parabiotic culture (no direct cell contact with Sertoli cells, but only humoral contact through medium) displayed radiolabelled nuclei (Fig. 2a) which were noticeably absent from peritubular myoid cell monocultures (Fig. 2b).

$\left[{ }^{3} \mathrm{H}\right]$ thymidine incorporation into DNA was measured by scintillation counting and autoradiography and the data are 


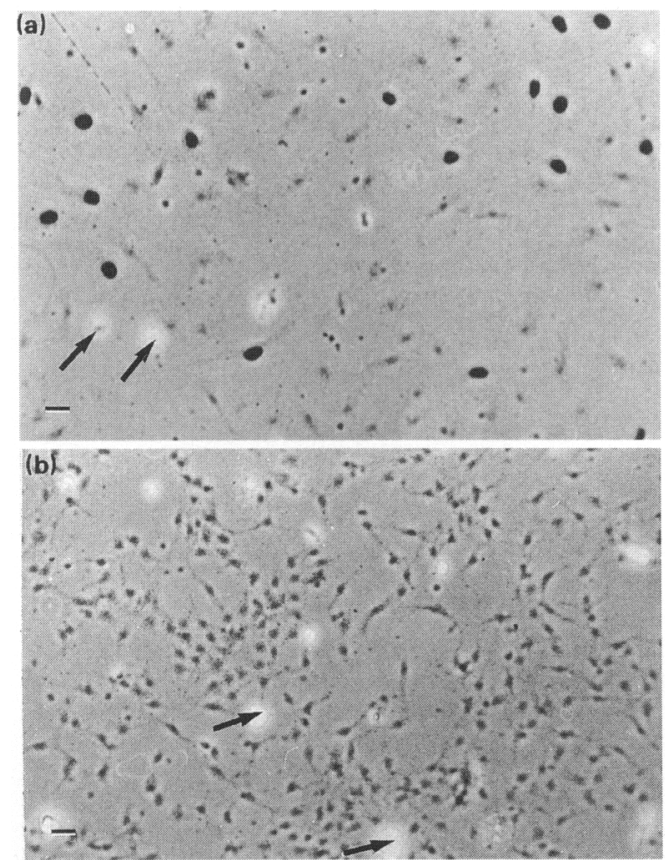

Fig. 2. Autoradiographs showing effects of factors secreted from Sertoli cells on DNA synthesis by rat peritubular myoid cells in a parabiotic culture situation. Parabiotic cultures had Sertoli cells on one side and peritubular myoid cells on the other side of a plastic partition across the middle of a Petri dish. Peritubular myoid cells in parabiotic culture as shown in (a) had no direct cell contact with Sertoli cells but only humoral contact through serum-free MEM. Under these conditions, peritubular myoid cells displayed radiolabelled nuclei (a) that were absent from monocultures of peritubular myoid cells maintained in serum-free MEM (b). Some dead contaminating germ cells are indicated by arrows. All cultures were incubated with $\left[{ }^{3} \mathrm{H}\right]$ thymidine $(2 \mu \mathrm{Ci}$ per dish) for $96 \mathrm{~h}$. Stain: haematoxylin and eosin. Scale bar $=10 \mu \mathrm{m}$.

expressed as c.p.m. per $10^{6}$ cells and percentage labelled nuclei (Table 1), respectively. Significantly more $\left[{ }^{3} \mathrm{H}\right]$ thymidine was incorporated into DNA in the peritubular myoid cell monocultures than in Sertoli cell monocultures. Coculture values were significantly higher than the monocultures. Addition of serum to peritubular myoid cell monocultures produced a significantly greater response than either of the monocultures or cocultures (Table 1).

\section{Cellular protein}

Total cellular protein data as corrected per cellular DNA ( $\mu \mathrm{g}$ protein per $\mu \mathrm{g}$ DNA) are given (Table 1 ). Sertoli-myoid cell cocultures showed a significantly higher value than the monocultures. Addition of serum to peritubular myoid cell monocultures produced a similar response as that for the Sertoli-myoid cell cocultures.

\section{Discussion}

In this study, fewer peritubular myoid cells than Sertoli cells plated. We examined the total cellular DNA in Sertoli cell monocultures, peritubular myoid cell monocultures and Sertolimyoid cell cocultures under serum-free conditions, and found that DNA values were $2-3 \mu \mathrm{g}$ per plate for myoid cell monocultures, $15-20 \mu \mathrm{g}$ per plate for Sertoli cell monocultures and 20-25 $\mu \mathrm{g}$ per plate for Sertoli-myoid cell cocultures. This reflects the lower seeding density of peritubular myoid cells $\left(2 \times 10^{5}\right.$ per plate) compared with Sertoli cells $\left(1 \times 10^{6}\right.$ per plate) cultured in the absence of serum. The relatively lower proliferative activity in Sertoli cells might be related to their physiological state of maturation. In the present study, Sertoli cells from 20-22-day-old rats did not divide in culture as indicated by the low labelling index; this finding supports earlier observations in vivo (Nagy, 1972; Orth, 1982).

We repeatedly observed that peritubular myoid cells in the presence of serum typically became confluent by day 4 and grew in the typical 'hill and valley' pattern characteristic of smooth muscle cells (Bressler and Ross, 1973). Upon subculturing on day 4 , however, peritubular myoid cells in the absence of serum appeared extremely flat and sparse, assuming a polygonal form. Cells replated and maintained in serum-free condition had a labelling index about 15-fold lower than those maintained in serum-supplemented conditions. The possible explanation for this difference is available in a study by Skinner et al. (1989), who reported an approximate sixfold stimulation in growth of peritubular cells in culture in the presence of $10 \%$ calf serum compared with those cultured without serum. In an earlier report, Tung and Fritz (1986) noted that fibroblastic peritubular cells plated on polystyrene in the presence of $10 \%$ calf serum had a relatively high labelling index. In addition to the results obtained for $\left[{ }^{3} \mathrm{H}\right]$ thymidine incorporation into DNA at the individual cell level, our DNA assay would also determine the stimulatory effects of serum on cell numbers (e.g. 8-10 $\mu \mathrm{g}$ per plate for myoid cell monocultures with FCS compared with $2-3 \mu \mathrm{g}$ per plate for myoid cell monocultures without FCS).

It is also known that the expression of $\alpha$-smooth muscle isoactin (Owens et al., 1986; Tung and Fritz, 1990) in smooth muscle cells and in peritubular myoid cells is related to their growth state. It is possible that, as suggested for smooth muscle cells by Chamley-Campbell et al. (1979, 1981), subcultured peritubular cells phenotypically modulate in response to serum mitogens as a prerequisite for cell proliferation. In serum-free conditions, these cells may modulate but not synthesize DNA or may be mainly in a quiescent stage. However, these cells are metabolically active as evidenced from the synthesis of proteins and the constituents of the extracellular matrix (Raychoudhury et al., 1992, 1993a, b). Nevertheless, many characteristics of differentiated cells are altered in culture, including morphology and contractile and biosynthetic properties (Chamley-Campbell et al., 1979; Yau-Young et al., 1981), and further studies are needed to extrapolate the results from in vitro studies to those done under in vivo conditions.

Our morphological and histochemical identification of cells provided evidence of cell purity in the Sertoli or peritubular myoid cell cultures and allowed more accurate assessment of metabolic functions in this study. Contamination by Leydig cells could also be ruled out by using the above mentioned criteria. However, one cannot exclude the possibility of the presence of small number of cells from interstitial precursors that might be added to peritubular myoid cell population. Since 
Table 1. Mean ( \pm SEM) values for $\left[{ }^{3} \mathrm{H}\right]$ thymidine incorporation into DNA of cultures of Sertoli cells and peritubular myoid cells from rat testes

$\left[{ }^{3} \mathrm{H}\right]$ thymidine incorporation into DNA

\begin{tabular}{|c|c|c|c|c|}
\hline \multirow[b]{2}{*}{ Method of assessment } & \multirow[b]{2}{*}{$\begin{array}{l}\text { Sertoli cell } \\
\text { monoculture }\end{array}$} & \\
\hline & & $\begin{array}{l}\text { Peritubular myoid } \\
\text { cell monoculture }\end{array}$ & $\begin{array}{l}\text { Sertoli-myoid } \\
\text { cell coculture }\end{array}$ & $\begin{array}{l}\text { Peritubular myoid } \\
\text { cell plus FCS }\end{array}$ \\
\hline Scintillation counting (c.p.m. per $10^{6}$ cells) & $900 \pm 61^{a}$ & $2850 \pm 120^{\mathrm{b}}$ & $22754 \pm 1230^{c}$ & $31073 \pm 1540^{d}$ \\
\hline Autoradiography (percentage nuclei labelled) & $1.6 \pm 0.2^{2}$ & $5.6 \pm 0.6^{\mathrm{b}}$ & $20 \pm 0.7^{c}$ & $86 \pm 3^{\mathrm{d}}$ \\
\hline Total cellular protein $\left(\mu \mathrm{g} \mu \mathrm{g}^{-1} \mathrm{DNA}\right)$ & $63 \pm 2^{a}$ & $73 \pm 5.4^{\mathrm{a}}$ & $106 \pm 9.5^{\mathrm{b}}$ & $110 \pm 8.9^{b}$ \\
\hline
\end{tabular}

Peritubular myoid cells from rat testes were cultured in MEM containing 10\% fetal calf serum (FCS), subcultured on day 4, and plated in serum-free MEM at a cell density of approximately $2 \times 10^{5}$ in $35 \mathrm{~mm}$ plastic culture dishes either alone or in coculture with Sertoli cells previously cultured for 4 days in serum-free medium. Subcultured peritubular myoid cells were also replated in MEM containing $10 \%$ FCS and became confluent after 3-4 days of culture. Sertoli cell-enriched primary cultures were maintained in serum-free MEM that contained $1 \times 10^{\circ}$ cells per $35 \mathrm{~mm}$ plastic culture dish. All cultures were incubated with $\left.{ }^{3} \mathrm{H}\right)$ thymidine $(2 \mu \mathrm{Ci}$ per dish) for $96 \mathrm{~h}$. Means in a row with different letters are significantly different $(P<0.05)$.

specific markers for precursor cells are not available, it was difficult for us as well as for other investigators (Teerds et al., 1989; Moore et al., 1992) to identify and characterize the precursors of Leydig cells.

The focus of the current study was on that aspect of Sertolimyoid cell cooperation that shows that Sertoli cells stimulate the specific synthesis of DNA by peritubular myoid cells in vitro. Moreover, in terms of amounts of cellular protein, coculture of peritubular myoid cells with Sertoli cells showed higher values than either of the monocultures alone, indicating that paracrine regulation of testicular protein depends on a cooperation between these two cell types. This contention is supported by other studies on metabolic cooperation between these two cell types (Hutson and Stocco, 1981; Skinner et al., 1985). The coculture of myoid cells with Sertoli cells resulted in abolition of the requirement for serum for maintenance and proliferation of myoid cells in vitro (Tung and Fritz, 1980). We have previously reported biosynthetic cooperations between Sertoli and peritubular myoid cells in terms of production of collagen (Raychoudhury et al., 1992) and glycosaminoglycan (Raychoudhury et al., 1993a). In a different coculture model, Tung and Fritz (1986) noted that regulation of proliferation might be determined by the nature of Sertoli cell surface with which the peritubular cells were in contact. In another study, we reported a specific substratum and cell contact between Sertoli cell extracellular matrix and peritubular myoid cells where peritubular myoid cells cultured on Sertoli cell extracellular matrix showed significantly increased synthesis of cell- and matrix-associated glycosaminoglycan compared with cultures on uncoated plastic (Raychoudhury et al., 1993b).

Some earlier observations from our laboratory showed that the production of fibronectin by myoid cells in vitro was enhanced in co- or parabiotic culture with Sertoli cells, and that myoid cells in parabiotic culture with Sertoli cells incorporated five times more $\left[{ }^{3} \mathrm{H}\right]$ thymidine than did their counterparts in monocultures (Thompson et al., 1985). The latter observation supports the results obtained in this study at the individual cell level using autoradiography in a parabiotic culture situation. Taken together with the results of this study this would indicate that DNA synthesis by peritubular myoid cells is modulated by secreted factors from Sertoli cells which may not be exclusively dependent on direct cell contact. It is possible that a mitogen produced by Sertoli cells acts to induce fibronectin production and deposition into the extracellular matrix of peritubular myoid cells, which may in turn allow peritubular myoid cell proliferation. The data obtained in the parabiotic culture showing the modulation by factors secreted by Sertoli cells of $\left[{ }^{3} \mathrm{H}\right]$ thymidine incorporation into peritubular myoid cell DNA do not exclude the possibility that mitogenic polypeptides from Sertoli cells, which include seminiferous growth factor (Feig et al., 1980, 1983), insulin-like growth factor I (Borland et al., 1984) and Sertoli cell-secreted growth factor (Buch et al., 1988), may influence the behaviour of peritubular myoid cells. Indeed, humoral factors may be of more consequence in vivo, where these cells are separated by a layer of extracellular matrix.

In summary, this study demonstrates, for the first time, that Sertoli cells stimulate replicative DNA synthesis in purified preparations of rat testicular peritubular myoid cells in vitro. The coculture results collectively indicate that the paracrine regulation of testicular function depends on cooperation between Sertoli cells and peritubular myoid cells.

The authors wish to thank C. F. Millette and S. C. Newton for their valuable suggestions. We gratefully acknowledge the encouragement of the late J. S. H. Elkington. This work was supported by the Griffith University Research Grants Scheme.

\section{References}

Bellvé AR and Zheng W (1989) Growth factors as autocrine and paracrine modulators of male gonadal functions Joumal of Reproduction and Fertility 85 771-793

Borland K, Mita M, Oppenheimer CL, Blinderman LA, Massague J, Hall PF and Czech MP (1984) The actions of insulin-like growth factors I and II on cultured Sertoli cells Endocrinology 114 240-246

Bressler RS and Ross MH (1973) On the character of the monolayer outgrowth and the fate of the peritubular myoid cells in cultured mouse testis Experimental Cell Research 78 295-302

Buch JP, Lamb DJ, Lipshultz LI and Smith RG (1988) Partial characterization of a unique growth factor secreted by human Sertoli cells Fertility and Sterility $\mathbf{4 9}$ 658-664

Chamley-Campbell J, Campbell GR and Ross R (1979) The smooth muscle cell in culture Physiological Review 59 1-59

Downloaded from Bioscientifica.com at 04/26/2023 11:51:52AM 
Chamley-Campbell JH, Campbell GR and Ross R (1981) Phenotype-dependent response of cultured aortic smooth muscle to serum mitogens journal of $C_{e} l l$ Biology 89 379-383

Chapin RE, Phelps JL, Miller BE and Gray TJB (1987) Alkaline phosphatase histochemistry discriminates peritubular cells in primary rat testicular cell culture Joumal of Andrology 8 155-161

Dorrington JH, Roller NF and Fritz IB (1975) Effects of follicle stimulating hormone on cultures of Sertoli cell preparations Molecular and Cellular Endocrinology 3 57-70

Fawcett DW (1975) Ultrastructure and function of the Sertoli cell. In Handbook of Physiology, pp 21-55 Eds DW Hamilton and RO Greep. American Physiological Society, Baltimore, MD

Feig LA, Bellvé AR, Horbach-Erickson N and Klagsbrun M (1980) Sertoli cells contain a mitogenic polypeptide Proceedings of the National Academy of Science USA 77 4774-4778

Feig LA, Klagsbrun M and Bellvé AR (1983) Mitogenic polypeptide of the mammalian seminiferous epithelium: biochemical characterization and partial purification Journal of Cell Biology 97 1435-1443

Gilula NB, Fawcett DW and Aoki A (1976) The Sertoli cell occluding junctions and gap junctions in mature and developing mammalian testis Development Biology 50 142-168

Hall PF, Kew D and Mita M (1985) The influence of temperature on the functions of cultured Sertoli cells Endocrinology 116 1926-1932

Hutson JC (1983) Metabolic co-operation between Sertoli cells and peritubular cells in culture Endocrinology 112 1375-1381

Hutson JC and Stocco DM (1981) Peritubular cell influence on the efficiency of androgen-binding protein secretion by Sertoli cells in culture Endocrinology $1081362-1368$

Janecki A and Steinberger A (1987) Vectorial secretion of transferrin and androgen binding protein in Sertoli cell cultures: effect of extracellular matrix, peritubular myoid cells and medium composition Molecular and Cellular Endocrinology 52 125-135

Karsten $U$ and Wollenberger A (1977) Improvements in the ethidium bromide method for direct fluorimetric estimation of DNA and RNA in cell and tissue homogenates Analytical Biochemistry 77 464-470

Louis BG and Fritz IB (1979) Follicle-stimulating hormone and testosterone independently increase the production of $\mathrm{ABP}$ by Sertoli cells in culture Endocrinology 104 454-461

Lowry OH, Rosebrough NJ, Farr AL and Randell RJ (1951) Protein measurement with the folin phenol reagent Joumal of Biological Chemistry $193265-275$

Mans RJ and Novelli GD (1961) Measurement of the incorporation of radioactive amino acids into protein by a filter-paper disk method Archives of Biochemistry and Biophysics 94 48-53

Marshall W, Lamey PJ and Ferguson MM (1980) A modified autoradiography technique applicable to coverglass cell cultures Medical Laboratory Science $\mathbf{3 7}$ 355-357

Moore A, Findlay K and Morris ID (1992) In-vitro DNA synthesis in Leydig and other interstitial cells of the rat testis Joumal of Endocrinology 134 247-255

Nagy E (1972) Cell division kinetics and DNA synthesis in the immature Sertoli cells of the rat testis Journal of Reproduction and Fertility 28 389-395

Ojeifo JO, Byers SW, Papadopoulos V and Dym M (1990) Sertoli cell-secreted protein(s) stimulate DNA synthesis in purified rat Leydig cells in vitro journal of Reproduction and Fertility 90 93-108
Orth J (1982) Proliferation of Sertoli cells in fetal and postnatal rats: a quantitative autoradiographic study Anatomical Record 203 485-492

Owens GK, Loeb A, Gordon D and Thompson MM (1986) Expression of smooth muscle-specific $\alpha$-isoactin in cultured vascular smooth muscle cells: relationship between growth and cytodifferentiation Journal of Cell Biology 102 343-352

Raychoudhury SS, Irving MG, Thompson EW and Blackshaw AW (1992) Collagen biosynthesis in cultured rat testicular Sertoli and peritubular myoid cells Life Sciences 50 1585-1596

Raychoudhury SS, Blackshaw AW and Irving MG (1993a) Hormonal modulation of the interactions of cultured rat testicular Sertoli and peritubular myoid cells: effects on glycosaminoglycan synthesis Journal of Andrology 14 9-16

Raychoudhury SS, Blackshaw AW and Irving MG (1993b) Rat Sertoli cell extracellular matrix regulates glycosaminoglycan synthesis by peritubular myoid cells in vitro Molecular Reproduction and Development 35 151-158

SAS User's Guide: Statistics (1985) Statistical Analysis Systems Institute, Inc., Cary, North Carolina

Skinner MK and Fritz IB (1985) Testicular peritubular cells secrete a protein under androgen control that modulates Sertoli cell functions Proceedings of the National Academy of Science USA 82 114-118

Skinner MK, Tung PS and Fritz IB (1985) Co-operativity between Sertoli cells and testicular peritubular cells in the production and deposition of extracellular matrix components Journal of Cell Biology 100 1941-1947

Skinner MK, Takacs K and Coffey RJ (1989) Cellular localization of transforming growth factor-alpha gene expression and action in the seminiferous tubule: peritubular cell-Sertoli cell interactions Endocrinology 124 845-854

Teerds KJ, de Rooij DG, Rommerts FFG, van den Hurk R and Wensing CJG (1989) Proliferation and differentiation of possible Leydig cell precursors after destruction of the existing Leydig cells with ethane dimethyl sulphonate: the role of LH/human chorionic gonadotrophin Journal of Endocrinology 122 689-696

Thompson EW, Elkington JSH and Blackshaw AW (1985) Sertoli cell influence on myoid cell growth and/or proliferation Proceedings of the 17th Annual Conference of the Australian Society of Reproductioe Biology. Adelaide Abstract 45

Tung PS and Fritz IB (1977) Isolation and culture of testicular cells: a morphological characterization. In Techniques of Human Andrology, pp 125-143 Ed. ESE Hafez. Elsevier/North-Holland Biomedical Press, Amsterdam

Tung PS and Fritz IB (1980) Interactions of Sertoli cells with myoid cells in vitro Biology of Reproduction 23 207-217

Tung PS and Fritz IB (1986) Cell-substratum and cell-cell interactions promote testicular peritubular myoid cell histotypic expression in vitro 115 155-170

Tung PS and Fritz IB (1990) Characterization of rat testicular peritubular myoid cells in culture: $\alpha$-smooth muscle isoactin is a specific differentiation marker Biology of Reproduction 42 351-365

Tung PS, Skinner MK and Fritz IB (1984) Fibronectin synthesis is a marker for peritubular cell contaminants in Sertoli cell-enriched cultures Biology of Reproduction 30 199-211

Welsh MJ and Wiebe JP (1975) Sertoli cells: a rapid method for obtaining viable cells Endocrinology 96 618-624

Yau-Young AO, Shio H and Fowler S (1981) Growth, biochemistry and morphology of isolated rabbit aortic smooth muscle cells maintained in the presence or absence of serum Joumal of Cellular Physiology 108 461-473 